\title{
Isotherms and Isosteric Heat Desorption of Hymenaea stigonocarpa Mart. Seeds
}

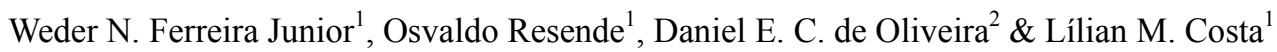 \\ ${ }^{1}$ Instituto Federal de Educação, Ciência e Tecnologia Goiano, Campus Rio Verde, Goiás, Brazil \\ ${ }^{2}$ Instituto Federal de Educação, Ciência e Tecnologia Goiano, Campus Iporá, Goiás, Brazil \\ Correspondence: Weder N. Ferreira Junior, Instituto Federal de Educação, Ciência e Tecnologia Goiano, Campus \\ Rio Verde, Goiás, Brazil. E-mail: wedernunesiftm@gmail.com
}

Received: June 14, 2018 Accepted: July 15, $2018 \quad$ Online Published: September 15, 2018

doi:10.5539/jas.v10n10p504

URL: https://doi.org/10.5539/jas.v10n10p504

\begin{abstract}
The Brazilian Cerrado is one of the most important ecosystems and due to the extractivism it is necessary to recover the degraded areas. The tree of Hymenaea stigonocarpa Mart. is used in this reforestation system, so the study of post-harvest management of the seed is necessary for the propagation. The objective of this work was to determine the isotherms and the isosteric desorption heat of Hymenaea stigonocarpa Mart. Seeds, and to test the methodology of the Akaike's information criterion (AIC) and Schwarz's bayesian information criterion (BIC) for the choice of the best mathematical model. Different mathematical models were fitted to the experimental data and the model that best represents the phenomenon was selected, from the statistical parameters. To obtain the equilibrium moisture content was used static method using desiccants in incubators cameras with control of relative humidity by salt solution. The Oswin Modified model obtained better results according to analyzed parameters, being this model the one selected for prediction of the hygroscopic balance of the Hymenaea stigonocarpa Mart. seeds. It was found that the higher the temperature for the same equilibrium moisture content, the higher the water activity values. The AIC and BIC methodology contributed to the choice of the best mathematical model to predict the hygroscopicity phenomenon. The isosteric heat increased with the decrease in the equilibrium moisture content requiring a greater amount of energy to remove water from the seeds.
\end{abstract}

Keywords: jatobá, hygroscopicity, moisture content, water activity

\section{Introduction}

The Cerrado has a great biodiversity, being the second largest Brazilian ecosystem. Interest in the propagation of Brazilian native species has intensified along with increasing environmental problems due to the expansion of agricultural areas and the need to preserve existing plant species. However, the knowledge available for seed production, storage and analysis of these species is limited (Sampaio, Couto, C. A. Silva, A. C. A. Silva, \& A. A. S. Silva, 2015).

Hymenaea stigonocarpa Mart. is a tree with the capacity to adapt to several Brazilian regions, especially the Amazon and the Cerrado, have good characteristics to be implemented in areas of recovery and environmental preservation. According to Rizzini (1978) the species is known in Brazil by jatobá, jutaí, jataí, burandá, courbaril, farinheira, among others. The Hymenaea stigonocarpa Mart. fruits have a characteristic flavor, and their pulp can used as an increase in culinary recipes as a source of fiber (E. P. Sousa, Silva, F. C. Sousa, Ferras, \& Façanha, 2012). This species has high economic potential, because in addition to the fruits, the wood of the tree can be destined for the civil construction. The leaves and seeds are used in the pharmaceutical industry (Farias, Cavalcanti Mata, Duarte, \& Lima, 2006).

The seeds of this species can also be destined to cooking as supplementation, according to Sousa et al. (2012) studied their nutritional characteristics for use in cooking. In order to ensure proper storage of seeds, it is necessary to know the hygroscopic behavior of the stored material, so as to enable the use of appropriate conditions to maintain product quality (Hong \& Ellis, 1996).

Water sorption isotherms derived by means of mathematical models together with isosteric liquid sorption heat are of paramount importance for post-harvest processes of plant products, such as drying and storage. The isosteric heat aims to estimate the energy consumed during drying, as well as to predict the behavior of the 
product during the processing, while the sorption isotherms allow the modeling of variations of water content according to temperature and relative humidity (Siripatrawan \& Jantawat, 2006; Catelam, Trindade, \& Romero, 2011; Comunian, Monterrey-Quintero, Thomazini, Balieiro, Piccone, Pittia, \& Favaro-Trindade, 2011).

Due to the social and environmental importance of this species, the objective was to determine the isotherms and isosteric heat of desorption of Hymenaea stigonocarpa Mart. Seeds, and as to test the Akaike information criterion (AIC) and Bayesian Schwarz information (BIC) to choose the best mathematical model.

\section{Material and Methods}

\subsection{Harvest of Fruits}

The Hymenaea stigonocarpa Mart. fruits has be collected in the municipality of Santa Helena de Goiás, Goiás, Brazil $\left(17^{\circ} 48^{\prime} \mathrm{S} ; 50^{\circ} 35^{\prime} \mathrm{W}\right)$, being manually depleted to obtain seeds without mechanical damage. The seeds contained $10.4 \%$ dry basis (d.b.) moisture content, determined according to Brasil (2009), in an oven at $105 \pm 3{ }^{\circ} \mathrm{C}$, during 24 horas. The experiment was carried out at the Laboratory of Post-Harvest of Vegetal Products of the Instituto Federal de Educação, Ciência e Tecnologia Goiano, Campus Rio Verde.

\subsection{Hygroscopicity of Seeds}

The equilibrium moisture content was obtained using the static method, in three replicates for each condition of temperature and relative humidity. Each replicate used approximately $12 \mathrm{~g}$ of seeds involved in a permeable fabric (voile), to allow the passage of air through the product, and then placed in desiccators. The control of the relative humidity inside the desiccators was used saturated solutions of different salts (Table 1). The desiccators were placed in B.O.D. (Biochemical Oxygen Demand) incubating chambers (Marconi), regulated at the temperatures of $20,25,30$ and $35^{\circ} \mathrm{C}$, the air temperature and relative humidity were monitored using a data logger (NOVUS), placed inside the desiccators.

Table 1. Values of relative humidity (\%) established in the air inside the desiccators, obtained experimentally and used to determine the hygroscopic equilibrium of Hymenaea stigonocarpa Mart. seeds, by the static method

\begin{tabular}{lllll}
\hline \multirow{2}{*}{ Chemical compound } & \multicolumn{4}{c}{ Temperature $\left( \pm 1^{\circ} \mathrm{C}\right)$} \\
\cline { 2 - 5 } & 20 & 25 & 30 & 35 \\
\hline $\mathrm{LiCl}$ (Lithium chloride) & 0.148 & 0.137 & 0.150 & 0.140 \\
$\mathrm{MgCl}$ (Magnesium chloride) & 0.378 & - & - & 0.350 \\
$\mathrm{NaCl}$ (Sodium chloride) & 0.794 & 0.770 & - & - \\
$\mathrm{KBr}$ (Potassium bromide) & - & - & 0.796 & 0.750 \\
$\mathrm{CaCl}_{2}$ (Calcium chloride) & - & 0.430 & 0.430 & 0.440 \\
\hline
\end{tabular}

Obtaining the equilibrium moisture content of the product was performed for different temperature controlled conditions $\left(20,25,30\right.$ and $\left.35^{\circ} \mathrm{C}\right)$ and water activity between 0.137 and 0.796 . The samples were weighed periodically until the hygroscopic equilibrium, that is, until when the mass change of the sample remained unchanged for three consecutive weighing. After reaching the hygroscopic equilibrium, the moisture content was determined in oven at 105 \pm during $24 \mathrm{~h}$ (Brasil, 2009).

\subsection{Mathematical Modeling}

The experimental values of equilibrium moisture content of the seeds were adjusted to mathematical models used to represent the hygroscopicity of vegetable products, whose expressions are presented in Table 2. 
Table 2. Mathematical models used to estimate the hygroscopicity of Hymenaea stigonocarpa Mart. seeds

\begin{tabular}{|c|c|c|}
\hline Equation & Model & \\
\hline$X e^{*}=\left[\ln \left(1-a_{w}\right) /\left(a \cdot T^{b}\right)\right]^{1 / c}$ & Cavalcanti Mata & (1) \\
\hline$X e^{*}=a-b \cdot \ln \left[-(T+c) \cdot \ln \left(a_{w}\right)\right]$ & Chung-Pfost & $(2)$ \\
\hline$X e^{*}=\exp \left[a-(b \cdot T)+\left(c \cdot a_{w}\right)\right]$ & Copace & (3) \\
\hline$X e^{*}=\left(a \cdot b \cdot c \cdot a_{w}\right) /\left[\left(1-c \cdot a_{w}\right) \cdot\left(1-c \cdot a_{w}+b \cdot c \cdot a_{w}\right)\right]$ & GAB & (4) \\
\hline$X e^{*}=\left[\exp (a-b \cdot T) /-\ln \left(a_{w}\right)\right]^{1 / c}$ & Modified Halsey & (5) \\
\hline$X e^{*}=\left\{\exp (a-b \cdot T) /\left[c-\ln \left(a_{w}\right)\right]\right\}^{1 / c}$ & Harkins & (6) \\
\hline$X e^{*}=\left[\ln \left(1-a_{w}\right) /-a(T+b)\right]^{1 / c}$ & Henderson Modificado & (7) \\
\hline$X e^{*}=a \cdot\left[a_{w} /\left(1-a_{w}\right)\right]^{b}$ & Oswin & $(8)$ \\
\hline$X e^{*}=(a+b \cdot T) \cdot\left[\left(1-a_{w}\right) / a_{w}\right]^{1 / c}$ & Modified Oswin & (9) \\
\hline$X e^{*}=\exp \left\{a-(b \cdot T)+\left[c \cdot \exp \left(a_{w}\right)\right]\right\}$ & Sigma Copace & (10) \\
\hline
\end{tabular}

Note. Xe* $=$ equilibrium moisture, $\%$ b.s.; $\mathrm{a}_{\mathrm{w}}=$ water activity, decimal; $\mathrm{T}=$ temperature, ${ }^{\circ} \mathrm{C} ; \mathrm{a}, \mathrm{b}$ and $\mathrm{c}=$ coefficients of model.

For the fit $\mathrm{f}$ mathematical models, nonlinear regression analysis was performed through the Gauss-Newton method using the program Statistica 7.0. The degree of fit of each model was evaluated based on the significance of the regression coefficients by t-test, magnitude of the determination coefficient $\left(\mathrm{R}^{2}\right)$, values of relative mean error (P), estimated (SE) and Chi-square test $\left(\chi^{2}\right)$ at 0.01 significance level and confidence interval of $99 \%$.

The relative and estimated mean errors and the Chi-square test for each model were obtained according to the following expressions, respectively:

$$
\begin{gathered}
P=\frac{100}{n} \sum \frac{|Y-\hat{Y}|}{Y} \\
S E=\sqrt{\frac{\sum(Y-\hat{Y})^{2}}{G L R}} \\
\chi^{2}=\sum \frac{(Y-\hat{Y})^{2}}{G L R}
\end{gathered}
$$

Where, $\mathrm{Y}=$ experimental value; $\hat{\mathrm{Y}}=$ estimated value by the model; $\mathrm{n}=$ number of experimental observations; $\mathrm{e}$, GLR: degree of freedom of the model.

\subsection{Parameters AIC and BIC}

The Hymenaea stigonocarpa Mart. fruits has be collected in the municipality of Santa Helena de Goiás, Goiás, Brazil (17 $\left.48^{\prime} \mathrm{S} ; 50^{\circ} 35^{\prime} \mathrm{W}\right)$, being manually depleted to obtain seeds without mechanical damage. The seeds contained $10,4 \%$ dry basis The Akaike information criterion (AIC) and the Schwarz bayesian information criterion (BIC) were used as secondary criterion for choosing the best mathematical model to predict the phenomenon. The AIC allows us to use the principle of parsimony in choosing the best model, that is, according to this criterion, the most parameterized model is not always the best (Bunham \& Anderson, 2004).

AIC is used to compare non-nested models or when three or more models are being compared, lower AIC values reflect a better fit (Akaike, 1974). Its expression. Is given by:

$$
\text { AIC }=-2 \log l i k e+2 p
$$

Where, $\mathrm{p}$ is the number of parameters, and loglike the value of the logarithm as a function of likelihood considering the parameter estimates.

The BIC also considers the degree of parameterization of the model, and in the same way, the smaller the BIC value (Schwarz, 1978), the better model adjustment. It is an asymptotic criterion whose adequacy is strongly related to the magnitude of the sample size. In relation to the sanction applied in the quantity of parameters, it will be more rigorous than the AIC for small samples. Its expression is given by:

$$
B I C=-2 \log l i k e+p \cdot \ln (n)
$$

Where, n: number of observation used to adjust the curve. 
Then, the isosteric integral desorption heat was determined, according to the methodology described by Chaves, Resende, Oliveira, Smaniotto, and Sousa (2015).

\section{Results and Discussion}

All the coefficients of determination $\left(\mathrm{R}^{2}\right)$ were higher that 0.94 decimal (Table 3), however according to Madamba et al. (1996), this coefficient should not be used as the sole evaluation criterion for selection of models.

Table 3. Coefficients of the models adjusted to the moisture content of hygroscopic equilibrium for the Hymenaea stigonocarpa Mart. seeds, with the statistical parameters analyzed

\begin{tabular}{|c|c|c|c|c|c|c|c|}
\hline Models & Coefficients & $\mathrm{SE}^{* * *}$ & P (\%) & $\chi^{2}$ & AIC & BIC & $\mathrm{R}^{2^{* * *}}$ \\
\hline 1 & $\begin{array}{l}\mathrm{a}=-0.00002^{\mathrm{ns}} \\
\mathrm{b}=1.03166^{* *} \\
\mathrm{c}=3.77740^{* *}\end{array}$ & 0.132 & 1.490 & 0.0170 & -11.2682 & -9.0084 & 0.9936 \\
\hline 2 & $\begin{array}{l}\mathrm{a}=11.3037^{* *^{-}} \\
\mathrm{b}=1.70467^{* *} \\
\mathrm{c}=2.37806^{\mathrm{ns}}\end{array}$ & 0.124 & 1.695 & 0.0153 & -12.8512 & -10.5914 & 0.9944 \\
\hline 3 & $\begin{array}{l}\mathrm{a}=1.63121^{* *} \\
\mathrm{~b}=0.00095^{* *} \\
\mathrm{c}=0.08963^{* *}\end{array}$ & 0.167 & 2.253 & 0.0279 & -5.0159 & -2.7562 & 0.9897 \\
\hline 4 & $\begin{array}{l}\mathrm{a}=4.67617^{* * *} \\
\mathrm{~b}=73.0262^{\mathrm{ns}} \\
\mathrm{c}=0.53709^{* *}\end{array}$ & 0.401 & 5.357 & 0.1605 & 17.7059 & 19.9657 & 0.9410 \\
\hline 5 & $\begin{array}{l}a=7.15343^{* *} \\
b=0.03283^{* *} \\
c=3.69281^{* *}\end{array}$ & 0.225 & 3.174 & 0.0507 & 2.7443 & 5.0041 & 0.9813 \\
\hline 6 & $\begin{array}{l}\mathrm{a}=3.04595^{* * *} \\
\mathrm{~b}=0.01039^{* *} \\
\mathrm{c}=1.77472^{* *}\end{array}$ & 0.121 & 1.698 & 0.015 & -8.8152 & -6.5554 & 0.9923 \\
\hline 7 & $\begin{array}{l}\mathrm{a}=0.00002^{* *} \\
\mathrm{~b}=-0.75733^{\mathrm{ns}} \\
\mathrm{c}=3.77679^{* *}\end{array}$ & 0.132 & 1.492 & 0.0170 & -11.2586 & -8.9988 & 0.9936 \\
\hline 8 & $\begin{array}{l}a=6.15844^{* *} \\
b=0.19579^{* *}\end{array}$ & 0.377 & 5.319 & 0.1420 & 15.3440 & 17.0389 & 0.9426 \\
\hline 9 & $\begin{array}{l}\mathrm{a}=7.80346^{* *} \\
\mathrm{~b}=-0.0587^{* *} \\
\mathrm{c}=5.22243^{* *}\end{array}$ & 0.121 & 1.685 & 0.0147 & -13.3616 & -11.1018 & 0.9946 \\
\hline 10 & $\begin{array}{l}\mathrm{a}=1.15971^{* * *} \\
\mathrm{~b}=0.00898^{* *} \\
\mathrm{c}=0.53119^{* *}\end{array}$ & 0.271 & 3.932 & 0.0736 & 7.5804 & 9.8402 & 0.9729 \\
\hline
\end{tabular}

Note. ${ }^{* *}$ Significant at 0.01 probability level by t-test; ${ }^{\text {ns }}$ Not significant; ${ }^{* * *}$ Decimal value.

The models of Cavalcanti Mata (1), Chung-Pfost (2), Harkins (6), Modified Henderson (7), and Modified Oswin (9) obtained a decimal R above 0.99, especially the Modified Oswin model with determination coefficient of 0.9946 decimal. However, this isolated parameter is not a reliable one to be used as the only source of analysis to select nonlinear models because they use the mean of negative and positive values that can leave the extreme values outside the parameters analyzed.

The models of Harkins (6) and Modified Oswin (9) presented the lowest values for the estimated mean error (0.121), while the GAB model (4) had the highest value (0.401). The ability of a mathematical model to represent hygroscopicity, being this phenomenon a physical process, is the ratio inversely proportional to the estimated mean error value (Draper \& Smith, 1981). All the studied models obtained values of the relative error 
below $10 \%$, which according to Mohapatra and Rao (2005), are adequate to represent the hygroscopicity of vegetal products.

Referring to the Chi-square test $\left(\chi^{2}\right)$, it can be observed that all models tested are in the $99 \%$ confidence interval, according to Günhan et al. (2005), the lower the Chi-square $\left(\chi^{2}\right)$ in the confidence interval, the better fit of the model in the representation of the studied phenomenon. Comparing the magnitude of the Chi-square $\left(\chi^{2}\right)$ test values (Table 3), the models of Cavalcanti Mata (1), Chung-Pfost (2), Harkins (6), Modified Henderson (7) and Modified Oswin (9) presented the lowest values compared to other models.

According to the statistical parameters traditionally evaluated for the choice of the best mathematical model to represent the hygroscopicity, all the models fit the selection criteria to estimate the desorption isotherms the Hymenaea stigonocarpa Mart. seeds.

Due to the need to include other selection criteria for a model that estimates the desorption isotherms, the Akaike information criterion (AIC) and Schwarz bayesian information criterion (BIC) methodology were suggested in this paper. The indication of the best model may be more precise, since these criteria consider other factors such as the analysis of the degree parametrization of the models compared (Silveira, 2010).

The Modified Oswin model (9) presented the lowest values for AIC and BIC, when compared to the other models, there being a greater difference between the values of these parameters in relation to those used traditionally. According to Gomes, Resende, Sousa, Oliveira, and Araújo Neto (2018) working to drying kinetics of crushed mass of 'jambu', lower AIC and BIC values indicate more adequate models.

According to the results, the Modified Oswin model (9) best fits the experimental values obtained by the static method to determine the hygroscopic equilibrium moisture content the Hymenaea stigonocarpa Mart. seeds. The same model was better suited to describe the isotherms of cumari yellow pepper seeds (Capsicum chinense L) (Ferreira, Silva, \& Rodovalho, 2011), among others (Corrêa, Reis, G. H. H. Oliveira, A. P. L. R. Oliveira, \& Botelho, 2015; Silva \& Rodovalho, 2016).

The equilibrium moisture content varied according to the changes in temperature and relative humidity (Figure 1). In order to achieve the same equilibrium moisture content, as the temperature increases, the higher the water activity values. These results corroborate with those obtained by other authors, such as: Caetano, Sousa, Resende, Sales, and Costa (2012), working with caju-árvore-do-cerrado (Anacardium othonianum Rizz.).

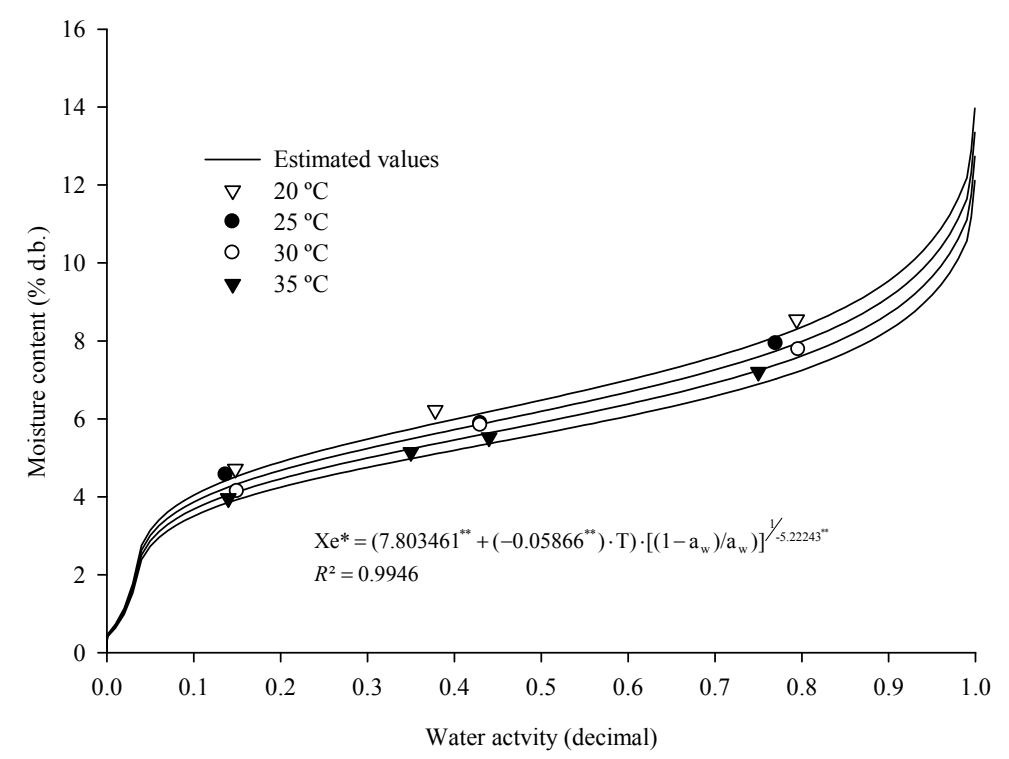

Figure 1. Experimental values of water activity and desorption isotherms estimated by the Modified Oswin model (9) for the Hymenaea stigonocarpa Mart. seeds and temperatures of 20, 25, 30, and $35^{\circ} \mathrm{C}$

The isotherms obtained for the Hymenaea stigonocarpa Mart. seeds following the trend of most vegetable products. It was observed that the increase in temperature causes an increase in water content decreased with increasing temperature, according to the literature: crambe (Crambe abyssinica) (Costa, Resende, \& Oliveira, 
2013), pepper (Capsicum chinense L.) (Silva et al., 2015). The desorption isotherms obtained for the Hymenaea stigonocarpa Mart. seeds by the Modified Oswin model (9) were presented in the sigmoidal format, as observed for most vegetable products such as castor beans (Ricinus communis L.) (Goneli, Corrêa, Oliveira, Resende, \& Mauad, 2016), beet seeds (Beta vulgaris) (Corrêa, G. H. H. Oliveira, A. P. L. R. Oliveira, Goneli, \& Botelho, 2016).

The values of equilibrium moisture content varied according to temperature increase $\left(20,25,30\right.$ and $\left.35^{\circ} \mathrm{C}\right)$, as well as the increase in water activity $(0.137$ to 0.796$)$, being a variable directly proportional to these conditions according to results obtained by Sousa, Resende, and Costa (2013) with forage turnip (Raphanus sativus L.) seeds.

In the post-harvest phase, the stored products become susceptible to attack by pathogens. Considering that the development of pathogenic microorganisms begins with the activity of water around 0.7 (Oliveira, Campos, Gomes, \& Silva, 2005), it is noted that the moisture content adequate to inhibit this action is at almost 7.59; 7.26; $6.92 ; 6.59$ (\% d.b.), for temperatures of 20, 25, 30 and $35^{\circ} \mathrm{C}$, respectively (Figure 1).

The experimental values obtained a good correlation with those estimated by the Modified Oswin (9); it can be seen in Figure 1. The limitation of the mathematical model in predicting the equilibrium moisture content of the Hymenaea stigonocarpa Mart. seeds occurs with decreasing water activity tendentiously to values close to zero, the same limitation was observed for the Chung-Pfost model for desorption isotherms of beet seeds (Beta vulgaris) (Corrêa et al., 2016).

The differential enthalpy values $\left(\mathrm{Dh}_{\mathrm{st}}\right)\left(\mathrm{kJ} \mathrm{kg}^{-1}\right)$ for Hymenaea stigonocarpa Mart. seeds were calculated as a function of equilibrium moisture content (\% d.b.). For the integral isosteric desorption heat $\left(\mathrm{Q}_{\mathrm{st}}\right)\left(\mathrm{kJ} \mathrm{kg}^{-1}\right)$ were added to the values of $\left(\mathrm{Dh}_{\mathrm{st}}\right)$, the value of the latent heat of vaporization of free water $\left(\mathrm{L}^{\prime}\right)$, which represents the minimum amount of energy required to evaporate the water, calculated for the average temperature of $27.5{ }^{\circ} \mathrm{C}$.

For the isosteric integral desorption heat $\left(\mathrm{Q}_{\mathrm{st}}\right)$, as a function of the equilibrium moisture content (\% d.b.) (Figure 2 ), it is noticed that, with the reduction in the moisture content, there was an increased in the energy required for the removal of water from the product. Similar behavior was observed for several vegetable products such as baru almonds (Dipteryx alata Vogel) (Furtado, Silva, Porto, \& Santos, 2014), cajuzinho-do-cerrado achenes (Anacardium humile St. Hil.) (Barbosa et al., 2016), pequi diaspore (Caryocar brasiliense, CAMB.) (Sousa, Resende, \& Carvalho, 2016).

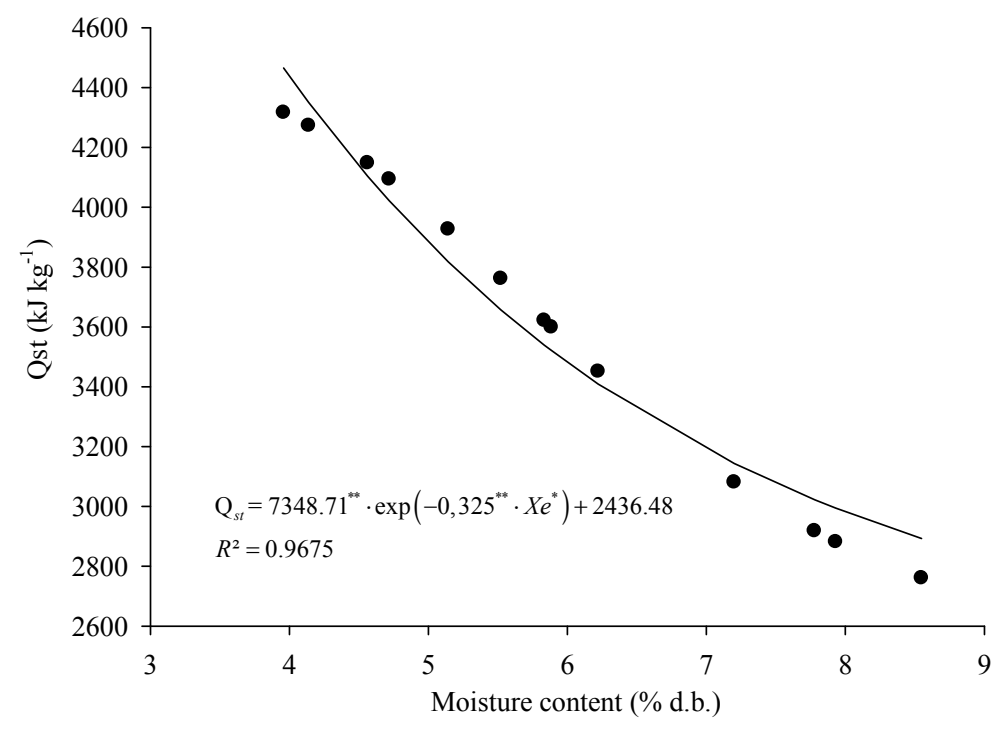

Figure 2. Experimental and estimated values of total isosteric desorption heat $\left(\mathrm{Q}_{\mathrm{st}}\right)$ estimated as a function of the equilibrium moisture content of the Hymenaea stigonocarpa Mart. seeds

Note. ${ }^{* *}$ Significant at 0.01 probability level by t-test. 
From the analysis of Figure 2, as well as that mentioned by Chaves et al. (2015), it can be seen that as the moisture content of the product decreases, more energy must be provided to remove water from the product. Oliveira, Resende, Smaniotto, Sousa, Campos (2013), working with corn seeds, obtained the variation of $2506 \mathrm{~kJ}$ $\mathrm{kg}^{-1}$ a $2734 \mathrm{~kJ} \mathrm{~kg}^{-1}$ for the water range from 23.3 to 12.8 (\% d.b.) results similar to this work, where the isosteric heat decreased with increasing moisture content.

The values of integral isosteric desorption heat for the Hymenaea stigonocarpa Mart. seeds in the range of equilibrium moisture content 3.96 to 8.55 (\% d.b.) ranged from 4316.22 to $2760.80 \mathrm{~kJ} \mathrm{~kg}^{-1}$. Sousa, Resende, Goneli, Smaniotto, and Oliveira (2015) working at temperatures of $25,30,35$ and $40{ }^{\circ} \mathrm{C}$ and relative humidity between 20 and $80 \%$ obtained equilibrium moisture contents ranging from 3.33 and 11.30 (\% d.b.) for fodder turnip seeds (Raphanus sativus L.), requiring amount of energy from 4222.70 to $2870.34 \mathrm{~kJ} \mathrm{~kg}^{-1}$ for removal of water. Comparing the results noted that the Hymenaea stigonocarpa Mart. seeds is less susceptible to loss of water during the drying process when compared to forage turnip seeds (Raphanus sativus $\mathrm{L}$.), this is due to the difference in chemical composition and seed structure, and since the coat of Hymenaea stigonocarpa Mart. seed is more rigid and less permeable.

\section{Conclusions}

The desorption isotherms of Hymenaea stigonocarpa Mart. seeds can be represented by all models tested according to traditional statistical parameters. The Modified Oswin model was chosen to predict the desorption isotherms of the Hymenaea stigonocarpa Mart. seeds for presenting better results for the AIC and BIC values, differing from the other models.

The Akaike information criterion (AIC) and Schwarz bayesian information criterion (BIC) contributed and were suitable for choosing the best mathematical model to estimate the desorption isotherms of Hymenaea stigonocarpa Mart. This methodology can be included in the model selection criterion to estimate the sorption isotherms of plant products.

The isosteric heat increases with the reduction of the equilibrium moisture content and a greater amount of energy is required to remove the water from Hymenaea stigonocarpa Mart. seeds, with values varying from 4316.22 to $2760.80 \mathrm{~kJ} \mathrm{~kg}^{-1}$, for the moisture content range of 3.96 to 8.55 (\% d.b.).

\section{Acknowledgements}

The authors extend thanks to IF Goiano, CAPES, FAPEG, FINEP and CNPq for their financial support, which was indispensable to the execution of this study.

\section{References}

Akaike, H. (1974). A new look at the statistical model identification. IEEE Transaction on Automatic Control, 19, 716-723. https://doi.org/10.1109/TAC.1974.1100705

Barbosa, K. F., Sales, J. F., Resende, O., Oliveira, D. E. C., Zuchi, J., \& Sousa, K. A. (2016). Desorption isotherms and isosteric heat of 'cajuzinho-do-cerrado' achenes. Revista Brasileira de Engenharia Agrícola e Ambiental, 20(5), 481-486. https://doi.org/10.1590/1807-1929/agriambi.v20n5p481-486

Brasil. (2009). Regras Para Análise de Sementes. MAPA/ACS, Ministério da Agricultura, Pecuária e Abastecimento, Secretaria Nacional de defesa Agropecuária.

Burnham, K. P., \& Anderson, D. R. (2004). Multimodel Inference: Understanding AIC and BIC in Model Selection. Sociological Methods \& Research, 33(2), 261-304. https://doi.org/10.1177/0049124104268644

Caetano, G. S., Sousa, K. A., Resende, O., Sales, J. F., \& Costa, L. M. (2012). Higroscopicidade de sementes de caju-de-árvore-do-cerrado. Pesquisa Agropecuária Tropical, 42(4), 437-445. https://doi.org/10.1590/ S1983-40632012000400012

Catelam, K. T., Trindade, C. S. F., \& Romero, J. T. (2011). Isotermas de adsorção e calor isostérico de sorção de polpa de maracujá desidratada por spray dryer e liofilizador com aditivos e leite desnatado. Ciência e Agrotecnologia, 35(6), 1196-1203. https://doi.org/10.1590/S1413-70542011000600021

Chaves, T. H., Resende, O., Oliveira, D. E. C., Smaniotto, T. A. S., \& Sousa. K. A. (2015). Isotermas e calor isostérico das sementes de pinhão-manso. Engenharia na Agricultura, 23(1), 9-18. https://doi.org/10.13083/ 1414-3984/reveng.v23n1p9-18

Comunian, T. A., Monterrey-Quintero, E. S., Thomazini, M., Balieiro, J. C. C., Piccone, P., Pittia, P., \& Favaro-Trindade, C. S. (2011). Assessment of production efficiency, physicochemical properties and storage stability of spray-dried chlorophyllide, a natural food colourant, using gum Arabic, maltodextrin 
and soy protein isolatebased carrier systems. International Journal of Food Science and Technology, 46(6), 1259-1265. https://doi.org/10.1111/j.1365-2621.2011.02617.x

Corrêa, P. C., Oliveira, G. H. H., Oliveira, A. P. L. R., Goneli, A. L. D., \& Botelho, F. M. (2016). Isotermas de dessorção de sementes de beterraba. Engenharia na Agricultura, 24(1), 15-21. https://doi.org/10.13083/ 1414-3984/reveng.v24n1p15-21

Corrêa, P. C., Reis, M. F. T., Oliveira, G. H. H., Oliveira, A. P. L. R., \& Botelho, F. M. (2015). Moisture desorption isotherms of cucumber seeds: modeling and thermodynamic properties. Journal of Seed Science, 37(3), 218-225. https://doi.org/10.1590/2317-1545v37n3149549

Costa, L. M., Resende, O., \& Oliveira, D. E. C. (2013). Isotermas de dessorção e calor isostérico dos frutos de crambe. Revista Brasileira de Engenharia Agrícola e Ambiental, 17(4), 412-418. https://doi.org/10.1590/ S1415-43662013000400009

Draper, N. R., \& Smith, H. (1998). Applied regression analysis (3rd ed.). John Wiley \& Sons, New York, NY. https://doi.org/10.1002/9781118625590

Farias, D. C., Cavalcanti Mata, M. E. R. M., Duarte, M. E. M., \& Lima, A. K. V. O. (2006). Qualidade fisiológica de sementes de jatobá submetidas diferentes temperaturas criogênicas. Revista Brasileira de Produtos Agroindustriais, 8(1), 67-74. https://doi.org/10.15871/1517-8595/rbpa.v8n1p67-74

Ferreira, S. C. S., Silva, H. W., \& Rodovalho, R. S. (2011). Isoterma de dessorção e calor latente de vaporização da semente de pimenta Cumari Amarela (Capsicum chinense L.). Revista Liberato, 12(18), $107-206$. https://doi.org/10.1590/1807-1929/agriambi.v19n8p780-784

Furtado, G. F., Silva, F. S., Porto, A. G., \& Santos, P. (2014). Dessorção e calor isostérico de amêndoas de baru. Revista Brasileira de Tecnologia Agroindustrial, 8(2), 1416-1427. https://doi.org/10.3895/S1981-36862014 000200010

Gomes, F. P., Resende, O., Sousa, E. P., Oliveira, D. E. C., \& Araújo Neto, F. R. (2018). Drying kinetics of crushed mass of 'jambu: Effective diffusivity and activation energy. Revista Brasileira de Engenharia Agricola e Ambiental, 22(7), 499-505. https://doi.org/10.1590/1807-1929/agriambi.v22n7p499-505

Goneli, A. L. D., Corrêa, P. C., Oliveira, G. H. H., Resende, O., \& Mauad, M. (2016). Moisture sorption isotherms of castor beans. Part 1: Mathematical modeling and hysteresis. Revista Brasileira de Engenharia Agrícola e Ambiental, 20(8), 751-756. https://doi.org/10.1590/1807-1929/agriambi.v20n8p751-756

Günhan, T., Demir, V., Hancioglu, E., \& Hepbasli, A. (2005). Mathematical modelling of drying of bay leaves. Energy Conversion and Management, 46(11), 1667-1679. https://doi.org/10.1016/j.enconman.2004.10.001

Hong, T. D., \& Ellis, R. H. (1996). A protocol to determine seed storage behaviour. Rome: International Plant Genetic Resources Institute.

Madamba, P. S., Driscoll, R. H., \& Bruckle, K. A. (1996). The thin-layer drying characteristics of garlic slices. Journal of Food Engineering, 29(1), 75-97. https://doi.org/10.1016/0260-8774(95)00062-3

Mohapatra, D., \& Rao, P. S. (2005). A thin-layer drying model of parboiled wheat. Journal of Food Engineering, 66(4), 513-518. https://doi.org/10.1016/j.jfoodeng.2004.04.023

Oliveira, D. E. C, Resende, O., Smaniotto, T. A. S., Sousa, K. A., \& Campos, R. C. (2013). Propriedades termodinâmicas de grãos de milho para diferentes teores de água de equilíbrio. Pesquisa Agropecuária Tropical, 43(1), 50-56. https://doi.org/10.1590/S1983-40632013000100007

Oliveira, M. M., Campos, A. R. N., Gomes, J. P., \& Silva, F. L. H. (2005). Isotermas de sorção do resíduo agroindustrial de casca do abacaxi (Ananas comosus L. Mer). Revista Brasileira de Engenharia Agrícola e Ambiental, 9(4), 565-569. https://doi.org/10.1590/S1415-43662005000400020

Raji, A. O., \& Ojediran, J. O. (2011). Moisture sorption isotherms of two varieties of millet. Food and Bioproducts Processing, 89(1), 178-184. https://doi.org/10.1016/J.FBP.2010.06.001

Rizzini, C. T. (1978). Plantas do Brasil: Árvores e Madeiras Úteis do Brasil-Manual de Dendrologia Brasileira. Edgard Blucher.

Sampaio, M. F., Couto, S. R., Silva, C. A., Silva, A. C. A., \& Silva, A. A. S. (2015). Influência de diferentes substratos associados a métodos de superação de dormência na germinação e emergência de sementes de jatobá (Hymenaea courbaril L.). Revista Farociência, 2(1), 11-27. 
Schwarz, G. (1978). Estimating the dimension of a model. Annals of Statistics, 6, 461-464. https://doi.org/ 10.1214/aos/1176344136

Silva, H. W., \& Rodovalho, R. S. (2015). Adsorption isotherms and vaporization latent heat of malagueta pepper seeds. Cientifica, 44(1), 5-13. https://doi.org/10.15361/1984-5529.2016v44n1p5-13

Silva, H. W., Costa, L. M., Resende, O., Oliveira, D. E. C., Soares, R. S., \& Vale, L. S. R. (2015). Higroscopicidade das sementes de pimenta (Capsicum chinense L.). Revista Brasileira de Engenharia Agricola e Ambiental, 19(8), 780-784. https://doi.org/10.1590/1807-1929/agriambi.v19n8p780-784

Silveira, F. G. (2010) Classificação multivariada de modelos de crescimento para grupos genéticos de ovinos de corte (Unpublished master's thesis, Universidade Federal de Viçosa, Brazil).

Siripatrawan, U., \& Jantawat, P. (2006). Determination of moisture sorption isotherms of jasmine rice crackers using BET and GAB models. Food Science and Technology International, 6(12), 459-465. https://doi.org/ $10.1177 / 1082013206072622$

Sousa, E. P., Silva, L. M. M., Sousa, F. C., Ferras, R. R., \& Façanha, L. M. (2012). Caracterização físico-química da polpa farinácea e semente do jatobá. Revista Verde de Agroecologia e Desenvolvimento Sustentável, 7(2), 117-121.

Sousa, K. A., Resende, O., \& Carvalho, B. S. (2016). Determination of desorption isotherms, latent heat and isosteric heat of pequi diaspore. Revista Brasileira de Engenharia Agricola e Ambiental, 20(5), 493-498. https://doi.org/10.1590/1807-1929/agriambi.v20n5p493-498

Sousa, K. A., Resende, O., \& Costa, L. M. (2013). Isotermas de dessorção das sementes de nabo forrageiro obtidas pelos métodos dinâmico e estático. Revista Brasileira de Engenharia Agrícola e Ambiental, 17(2), 216-222. https://doi.org/10.1590/S1415-43662013000200013

Sousa, K. A., Resende, O., Goneli, A. L. D., Smaniotto, T. A. S., \& Oliveira, D. E. C. (2015). Thermodynamic properties of water desorption of forage turnip seeds. Acta Scientiarum, 37(1), 11-19. https://doi.org/ 10.4025/actasciagron.v37i1.19333

\section{Copyrights}

Copyright for this article is retained by the author (s), with first publication rights granted to the journal.

This is an open-access article distributed under the terms and conditions of the Creative Commons Attribution license (http://creativecommons.org/licenses/by/4.0/). 